\title{
INTERPRETING CUSTOMARY RIGHTS ORDERS UNDER THE FORESHORE AND SEABED ACT: THE NEW JURISDICTION OF THE MĀORI LAND COURT
}

\author{
Shaunnagh Dorsett" and Lee Godden **
}

The Foreshore and Seabed Act 2004 inaugurated a new jurisdiction for the Māori Land Court with respect to customary rights orders over areas of the foreshore and seabed. This article focuses on the customary rights orders provisions of the Act. While this new jurisdiction is entirely statutory, the language of the provisions reflects the common law "tests" for aboriginal rights and native title. This article looks, therefore, to the common law as a possible guide for interpretation of the CRO provisions. It concludes, however, that the statutory language of the Act provides an opportunity for New Zealand courts, and the Māori Land Court in particular, to forge a new body of jurisprudence, one which hopefully will avoid the strictures and inequalities of its common law equivalent.

\section{INTRODUCTION}

In April 2005 the first application for a customary rights order under the Foreshore and Seabed Act was lodged with the Māori Land Court. ${ }^{1}$ In many ways, this application inaugurates a new era in the ongoing controversy over Māori claims to the foreshore and seabed. Undoubtedly the debate over the foreshore and the new legislation will continue in political and other arenas. ${ }^{2}$ However,

Senior Lecturer, Faculty of Law, Victoria University of Wellington. The authors wish to thank Dean Knight and Andrew Erueti of Victoria University of Wellington's Law Faculty for helpful discussions relating to several provisions of the Foreshore and Seabed Act 2004.

** Senior Lecturer, Faculty of Law, University of Melbourne.

1 Foreshore and Seabed Act 2004: The first claim, by Whakatohea from the eastern Bay of Plenty, relates to a forty kilometre stretch of coastline between Te Horo and Te Rangi, near Whakatane, and includes claims for rangatiratanga and kaitiakitanga.

2 For example, the National Party announced that should it be successful in the 2005 general election, it would look to "change the foreshore law to prevent the Māori Land Court hearing customary rights cases and investigate axing the Court altogether" (18 April 2005) New Zealand Herald Auckland; see also 
New Zealand courts are now faced with the task of constructing a new body of jurisprudence. In so doing, they are entering new territory. While New Zealand has a long history of dealing with Māori land law through the Māori Land Court process and Treaty of Waitangi claims, native or aboriginal title claims have been comparatively rarely judicially discussed in this country. Despite the early acknowledgment of the existence of Māori proprietary rights to the land, ${ }^{3}$ aboriginal title did not develop as, for example, in the United States, in part because the need was overtaken by other processes, such as those available through the Māori Land Court or the Waitangi Tribunal. The resurgence of interest in aboriginal title in the 1990s did not lead to a developed body of jurisprudence. ${ }^{4}$ New Zealand courts now have that opportunity, albeit with reference to a statutory rather than common law jurisdiction.

The purpose of this article is to consider the customary rights orders provisions under the Foreshore and Seabed Act. Specifically, the article examines non-territorial customary rights orders (CROs). There have been a number of works since the Ngati Apa which have considered both the decision itself and the resulting legislation. ${ }^{5}$ However, in the main these focus on territorial customary rights. Little, to date, has been written on the new CRO provisions. ${ }^{6}$ Sections 50 and 74 of the Foreshore and Seabed Act create new parallel, but not identical, jurisdictions for the High Court and the Māori Land Court with respect to the identification of non-territorial customary rights. The jurisdiction of the Māori Land Court is narrower than that of the High Court. The Māori Land

"Foreshore and seabed back on the agenda" (31 March 2005) New Zealand Herald Auckland, editorial; National Party "The Beach Belongs to Everyone" (7 April 2005) Press Release.

3 See $R v$ Symonds (1847) [1840-1932] NZPCC 387 (SC); Re Lundon and Whitaker Claims (1872) 2 NZCA 41 (CA); Nireaha Tamaki v Baker [1901] AC 561 (PC). To the contrary see Nireaha Tamaki v Baker (1894) 11 NZLR 483 (CA); Hohepa Wi Neera v Bishop of Wellington (1902) 21 NZLR 655 (CA).

4 The leading case is Te Runanganui o Te Ika Whenua Inc Society v Attorney-General [1994] 2 NZLR 20 (CA), in which it was determined that aboriginal title is part of the law of New Zealand. Cooke P outlined the main features of aboriginal title: 23, 24. See also Te Runanga o Wharekauri Rekohu Inc v AttorneyGeneral [1993] 2 NZLR 301 (CA); Ngai Tahu Māori Trust Board v Director General of Conservation [1995] 3 NZLR 533 (CA).

5 Attorney-General v Ngati Apa [2003] 3 NZLR 643 (CA); there have been a number of works since Ngati Apa, which have considered either various aspects of aboriginal title in New Zealand, or the legislative response itself. However, these have in the main concentrated on territorial customary rights. However, the focus on these pieces is territorial customary rights, rather than the non-territorial customary rights: see Richard Boast "Māori Proprietary Claims to the Foreshore and Seabed after Ngati Apa" (2004) 21 NZULR 1; Paul McHugh "Aboriginal Title in New Zealand: A Prospect and Retrospect" (2004) 2 NZJPIL 139 ["Aboriginal Title in New Zealand"]. See also Tom Bennion, Malcolm Birdling and Rebecca Paton Making Sense of the Foreshore: A Special Edition of the Māori Law Review (Wellington, 2004).

6 One exception is the brief discussion of the CRO provisions in Paul McHugh "From Common Law to Codification - the Foreshore and Seabed Act 2004" in Bronwyn Arthur, Paul McHugh, Camilla Owen, Foreshore and Seabed Act, the RMA and Aquaculture (New Zealand Law Society, 2005) ["From Common Law to Codification"]. 
Court may hear applications from whānau, hapū or iwi with respect to activities, uses or practices which are integral to tikanga Māori. ${ }^{7}$ The parallel, but not identical, High Court provision is section 74. It provides that the High Court may also make CROs, however these are not limited to applications by whānau, hapū or iwi, but apply to applications from a "group of natural persons". This provision, therefore, reflects a political compromise in so far as it makes CROs available to Māori and non-Māori alike. However, while section 74 does on its face apply to Māori applicants, the Act then limits the High Court's jurisdiction by stating that it may not inquire into a claim which is "able to be recognised and protected by an order made by the Māori Land Court under Part $3 " .{ }^{8}$ In effect, therefore, the High Court can only hear claims by non-Māori, and it is suggested that there will be few of these. As a result, despite the apparent creation of dual jurisdictions, it is the Māori Land Court which will be the primary body through which jurisprudence relating to CROs is developed.

The definition of a CRO, as well as the requirements for proof and extinguishment, are set out in some detail in the Act. The criteria embedded in the legislation echo those of the common law, in particular from both Canadian and Australian jurisprudence in this area. That the understanding of native or aboriginal title which underpins the Act would include aspects of jurisprudence from other common law jurisdictions was probably inevitable. As McHugh explains: ${ }^{9}$

... with the decision to replace the common law jurisdiction with a statutory version, it became necessary to form some idea, however speculative, of what was being replaced. By that measure the Government's proposals could be gauged. Political circumstance made inevitable the speculative exercise that the Court of Appeal had properly seen as unnecessary.

While the "tests" in section 50 broadly reflect the common law, the jurisdiction of the Māori Land Court is entirely statutory. We can only speculate about whether or not those who designed the legislation anticipate that New Zealand courts will adopt or echo jurisprudence from other jurisdictions. Nevertheless, the incorporation of language reflective of common law jurisprudence is likely to result in guidance being sought from the case law which inspired the legislation, either by

7 Foreshore and Seabed Act 2004, s 50.

8 Foreshore and Seabed Act 2004, s 73(1)(a)(i).

9 "Aboriginal Title in New Zealand", above n 5, 142; the Select Committee Report on the Foreshore and Seabed Bill provides a clue as to the understanding of Māori customary rights which underpin the legislation: according to the Report the Labour and Progressive parties' view of customary rights is reflective of a view of customary rights presented by Angela Ballara and cited in Boast and others Māori Land Law (2 ed, LexisNexis, Wellington, 2004): "The land or the waters of the lake, lagoon or harbour or open sea was not the taonga (property) owned; what was owned were the rights to certain resources within a particular territory: the right to gather certain crops first (berries, wild vegetables), the right to let down a seine at certain fishing places, the right to catch birds nesting on a specific tree, or the rats (kiore) using a particular rat run; if the birds or rats moved to another tree or run, or the shoals swam elsewhere, they could be caught by others". Foreshore and Seabed Bill 2004, no 129-1 (the commentary) 8. 
claimants seeking to "push the boundaries" of the legislation or, more likely, by those seeking to restrict the range and quality of rights which can be recognised. In effectively creating a "code" by reference to an existing body of jurisprudence, and incorporating specific language into the new Act, it is inevitable also that judges, in particular those less experienced in tikanga Māori, will look to the common law in interpreting and applying the legislation. This is, after all, standard common law technique. One only needs to look to the decisions of courts with respect to criminal law in any jurisdiction which has codified that body of law. This article, therefore, looks at the suggested provenance of certain words and phrases used in Part 3, subpart 2 (the CRO provisions) and in particular in sections 49,50 and 51, examines the context in which they were developed and the kinds of rights and interests that have been recognised in Canada and Australia. The argument is not, however, that the CRO provisions should, or will necessarily, be interpreted in the same way. To the contrary, there are good reasons to hope that this will not be the case. Both Australian and Canadian courts have rightly been criticised for the narrow, legalistic approach that they have taken to the recognition of aboriginal rights. ${ }^{10}$ However, the fact that the Act inaugurates a new statutory jurisdiction means that New Zealand Courts (and in particular the Māori Land Court), have a unique opportunity to develop a new body of jurisprudence, constrained only by the language of the legislative provisions themselves.

\section{THE CRO PROVISIONS}

Broadly speaking, these requirements in sections 49,50 and 51 for a CRO mirror the "twostage" test for aboriginal or native title rights at common law. The first stage, the proof stage, incorporates aspects of both Australian and Canadian common law tests for recognition. The second stage, an inquiry into whether or not the rights have been extinguished, both incorporates the Australian inconsistency test, and introduces new "extinguishing events".

According to sections 49(2) and 50(1), a claimant whānau, hapū or iwi must be able to show:

(1) an activity, use or practice which has a physical manifestation in an activity relating to a natural or physical resource; and

(2) which is integral to tikanga Māori since 1840; and

(3) which has been carried on in a substantially uninterrupted manner since 1840; and

(4) which is neither prohibited by any enactment or rule of law nor extinguished as a matter of law.

10 On the approach of the Australian High Court see Noel Pearson "The High Court's Abandonment of the "Time Honoured Methodology of the Common law" in its Interpretation of Native Title in Murriuwung Gajerrong and Yorta Yorta" (2003 Sir Ninian Stephen Annual Lecture, Law School University of Newcastle, 17 March 2003) 6. 
Section 51 provides further detail as to the circumstances in which an activity, use or practice has been either substantially interrupted or extinguished.

As far as the first limb, proof, is concerned, the sections fuse the normative approach which characterises Australian native title doctrine with the Canadian requirement that a practice be "integral". Somewhat simplified, "normative"11 refers to the approach whereby the content of native title is determined by reference to the customs and traditions of the claimant group. ${ }^{12}$ This approach has been explained most succinctly by the majority of the High Court in Fejo v Northern Territory: $:^{13}$

Native title has its origin in the traditional laws acknowledged and the customs observed by the indigenous people who possess the native title. Native title is neither an institution of the common law nor a form of common law tenure but it is recognised by the common law. There is, therefore, an intersection of traditional laws and customs with the common law. The underlying existence of the traditional laws and customs is a necessary pre-requisite for native title but their existence is not a sufficient basis for recognising native title.

The requirement that the activity, use or practice be integral to "tikanga Māori" incorporates a similar approach as the content of a CRO will presumably be determined by evidence as to what constitutes tikanga Māori for the particular claimant group with respect to a defined area of foreshore. Married to that requirement is a further constraint that the practices be "integral" to tikanga Māori. This is substantially the same requirement as forms part of the Canadian test for aboriginal rights. In order to prove an aboriginal right that right must be shown to be "integral to the distinctive culture" of the claimant group. ${ }^{14}$ Finally, any activity, use or practice must have been carried on in accordance with tikanga Māori in a substantially uninterrupted manner since 1840. The requirement that customs and traditions be substantially uninterrupted, or continuous, forms part of

11 On "normative systems" see Sean Brennan, Brenda Gunn and George Williams "Sovereignty and Its Relevance to Treaty-making between Indigenous Peoples and Australian Governments" (2004) 26 Syd LR 307, 327; Kirsten Ankar "Law in the Present Tense: Tradition and Cultural Continuity in Members of the Yorta Yorta Aboriginal Community v Victoria" (2004) 28 MULR 27.

12 Mabo v State of Queensland (No 2) (1992) 175 CLR 1 (HCA), particularly the judgment of Brennan J. The findings of fact in that case were crucial and the process by Justice Moynihan has not escaped criticism, see Nonie Sharp "No Ordinary Case: Reflections upon Mabo (No 2)" (1993) 15 Syd LR Review 143, 151-6.

13 Fejo v Northern Territory (1998) 195 CLR 96, 128 (HCA), Gleeson CJ, Gaudron, McHugh, Gummow, Hayne and Callinan JJ (footnotes omitted, emphasis in original).

14 See $R v$ Van der Peet (1996) 137 DLR $\left(4^{\text {th }}\right) 289$ (SCC). 
both native title doctrine in Australia, ${ }^{15}$ and aboriginal rights jurisprudence in Canada. ${ }^{16}$ All three of these above requirements have proven problematic in the jurisdictions from which they are derived.

Inevitably, the development of any body of common law jurisprudence occurs piecemeal and unevenly. Specific issues can only be dealt with if and when they are raised directly before the court. As the rest of this paper indicates, in both Australia and Canada the courts have been faced with a number of similar problems. While the form that these problems has taken differs between jurisdictions, the outcomes for Indigenous claimants have been similar. In addition, some crucial issues remain to be determined in both jurisdictions. The Foreshore and Seabed Act clearly attempts to "side-step" a number of these unresolved and contentious issues by providing specific statutory criteria with respect to them. For example, while it is unclear in Australia whether a spiritual connection (or association) with the land would be sufficient to found native title, ${ }^{17}$ and indeed there is some jurisprudence to suggest that the Foreshore and Seabed Act forecloses that possibility in section 49(2). ${ }^{18}$ Nevertheless, as will be seen, there is still significant scope for the courts, and in particular the Māori Land Court, to stamp their authority on these new provisions. The Māori Land Court is not bound by existing common law jurisprudence relating to particular words or phrases, and in addition has significant judicial discretion with respect to the threshold that must be met evidentially in order to satisfy requirements such as "integral" and "substantially uninterrupted". 19

\section{ACTIVITY, USE OR PRACTICE}

Section 50 of the Foreshore and Seabed Act refers to "activity, use or practice ... in the area of the public foreshore and seabed specified in the application". These words immediately conjure a "listing" or "bundling" approach to the recognition of rights. ${ }^{20} \mathrm{CROs}$ are intended to encompass bundles of rights which are insufficient to amount at common law to territorial claims. The

15 Members of the Yorta Yorta Community v Victoria (2002) 194 ALR 538, para $42-44$ (HCA) Gleeson CJ, Gummow and Hayne JJ; see Maureen Tehan "A Hope Disillusioned, An Opportunity Lost? Reflections on Common Law Native Title and Ten Years of The Native Title Act" (2003) 27 MULR 523, 557-8.

16 See John Burrows "Frozen Rights in Canada: Constitutional Interpretation and the Tickster" (1997) 22 Am Indian Law Review 37, 39 ["Frozen Rights in Canada"].

17 Western Australia v Ward (2002) 191 ALR 1 (HCA), para 57-61 Gleeson CJ, Gaudrom, Gummow and Hayne JJ.

18 See Western Australia v Ward, above n 17, para 252 Gleeson CJ, Gaudrom, Gummow and Hayne JJ.

19 For an example of the crucial role of the nature and type of evidence that is considered in relation to the satisfaction of these "tests" see Justice Olney's decision in Members of the Yorta Yorta Community v Victoria [1998] FCA 1606 (FCA) [Yorta Yorta (FCA)]. For a critique see James Cockayne "Members of the Yorta Yorta Aboriginal Community v Victoria: Indigenous and Colonial Traditions in Native Title" (2001) 25 MULR 786.

20 This accords with the description of aboriginal rights given to the Waitangi Tribunal by Paul McHugh: Waitangi Tribunal Report on the Crown's Foreshore and Seabed Policy (WAI 1071, Legislation Direct, Wellington, 2004) 52. 
dichotomy between non-territorial and territorial claims underpins Williamson J's decision in $T e$ Weehi and roughly equates to the bifurcation in Canada between site-specific aboriginal rights and aboriginal title which derives from the jurisprudence of the Supreme Court of Canada relating to section 35(1) of the Constitution Act 1982.21 This is the provision which protects "existing aboriginal rights", in other words those rights existing in 1982, the date at which the section was enacted. ${ }^{22}$ From a number of Supreme Court decisions, it is clear that for the purposes of that section aboriginal rights include, but are not limited to, aboriginal title. Rather, aboriginal rights exist on a spectrum, ranging from practices, customs and traditions which are integral to the distinctive culture of the land, but which do not amount to a possessory claim sufficient to found aboriginal title to a right to the land itself in the form of aboriginal title. ${ }^{23}$ Thus, site-specific aboriginal rights in Canada are those which are "integral to the distinctive culture of the group claiming the right". ${ }^{24}$ They may or may not be activities which are intimately connected with land, but they do not demonstrate the possession required to found aboriginal title. ${ }^{25}$ Rather, similar to the purported intent of the CRO provision, site-specific aboriginal rights are those bundles of rights which are insufficient to amount to territorial claims.

The problem, of course, with the bundling approach, or the "site-specific" approach is that it reflects a western, common law understanding of property rights. ${ }^{26}$ This is hardly surprising, and is also the case with respect to Australian native title and Canadian aboriginal rights jurisprudence. In Australia in particular, recognition of rights has been almost exclusively limited to site-specific physical activities. This is despite the constant reiteration by the High Court that it is inappropriate to force native title rights to conform to western notions of property. ${ }^{27}$ Rights recognised strongly reflect traditional common law profits-a-prendre such as hunting and fishing and attempts to argue

21 Te Weehi v Regional Fisheries Officer [1986] 1 NZLR 680, 692 (HC), in that case, Williamson J held that in which it was found that customary Māori fishing rights for the purposes of personal consumption could exist in the form of a non-territorial right; Constitution Act 1982 (Canada Act 1982 (UK), sch B).

22 Constitution Act 1982, s 35(1) provides that: The existing aboriginal and treaty rights of the aboriginal peoples of Canada are hereby recognised and affirmed.

23 Delgamuukw v British Columbia (1997) 153 DLR $\left(4^{\text {th }}\right)$ 193, para 138 (SCC) Lamer CJ, Cory and Major JJ.

$24 \quad R v$ Van der Peet, above $\mathrm{n} 14$.

25 For an examination of the manner in which concepts of aboriginal title based around the principles enunciated in Delgamuukw could be applied to sea spaces see Rebecca Brown and James Reynolds "Aboriginal Title to Sea Spaces: A Comparative Study" (2004) 37 UBCLR 449, 458-9.

26 For a discussion of how native title rights are framed against the parameters of Western property concepts see Lee Godden "Grounding Law as Cultural Memory: A Proper Account of Property and Native Title in Australian Law and Land" (2003) 19 AFLJ 63.

27 Mabo $v$ State of Queensland (No 2), above n 12, 84 Brennan J, quoting Amodu Tijani v Southern Nigeria (Secretary) [1921] 2 AC 399, 403 (PC). 
for a broader recognition of rights have largely met with a lack of success. ${ }^{28}$ The Foreshore and Seabed Act refers to "activity, use or practice" and requires a physical manifestation relating to a natural or physical resource. ${ }^{29}$ This appears to be a deliberate attempt on the part of the drafters to limit the rights which can be recognised under a customary rights order and possibly reflects a wariness on the part of the legislature of giving too broad a jurisdiction to the Māori Land Court.

It is, of course, at this stage unclear what kinds of rights will be recognised under section 50 . There are few clues in the Act as to the potential content of a CRO. However, given the language of "activity, use or practice" and the requirement of a physical manifestation, it seems likely that a similar range of rights to those recognised in Australia will be encompassed by the provision. Access rights generally, and to wāhi tapu in particular, the right to gather some coastal flora, possibly some rights to take sand, rights of navigation and landing, for example, all seem likely to be recognised. In fact, this is a similar list to the native title rights recognised in the Australian decision of Yarmirr. The trial judge's order in that case stated that: ${ }^{30}$

The native title rights and interests which the Court considers to be of importance are the rights of the common law holders, in accordance with and subject to their traditional laws and customs to have free access to the sea and sea-bed within the claimed area for all or any of the following purposes:

(a) to travel through or within the claimed area;

(b) to fish and hunt for the purpose of satisfying their personal, domestic or non-commercial communal needs including the purpose of observing traditional, cultural, ritual and spiritual laws and customs;

(c) to visit and protect places which are of cultural and spiritual importance;

(d) to safeguard their cultural and spiritual knowledge.

A similar set of "listed" native title rights were found in the most recent offshore native title decision in The Lardil People v Queensland. ${ }^{31}$ That case involved a claim for native title rights and interests in the sea "as far as they eye could see". ${ }^{32}$ The applicants also asserted that the claimant groups owned the seas, the seabed, the subsoil below the seabed and the resources of the seas in their respective territories. Cooper J held that native title consisted of hunting, fishing and gathering for domestic or non-commercial communal consumption; the right to take and consume fresh

28 See for example, Bulun Bulun $v R \&$ T Textiles Pty Ltd (1998) 157 ALR 193 (FCA).

29 On the narrowing focus of the Australian High Court on physical occupation and control over physical resources see Lisa Wright "Themes Emerging from the High Court's Recent Native Title Decisions" (Occasional Paper 1, National Native Title Tribunal, Perth, 2003).

30 Yarmirr v Northern Territory (1998) 156 ALR 370 (FCA), para 162 Olney J.

31 The Lardil Peoples $v$ State of Queensland [2004] FCA 298.

32 The Lardil Peoples $v$ State of Queensland, above n 31, para 15 Cooper J. 
drinking water from springs in the inter-tidal zone; and access to land and waters seaward of the high water line for hunting, gathering and religious, spiritual or ceremonial purposes. ${ }^{33}$ Cooper $\mathbf{J}$ also held that the claim of a "right to speak for country" was too imprecise for the Native Title Act. ${ }^{34}$ Notably, most of the rights found in both Yarmirr and Lardil Peoples already adhered to the group prior to any determination of native title, and in fact can be exercised by members of the public generally.

Problematically, a "listing" approach tends not only to lead to the recognition of an impoverished set of rights, but sits uncomfortably with the holistic way in which Indigenous groups around the world view their relationship to traditional lands. The "listing" approach reflects nonIndigenous common law property analysis, not Indigenous relationships to traditional country or sea. The High Court of Australia has stated that this result is an inevitable consequence of any process in which relationships and rights from one culture and jurisdiction are recognised and given juridical form in another jurisdiction. In Western Australia $v$ Ward the majority stated that: ${ }^{35}$

\footnotetext{
[t]he difficulty of expressing a relationship between a community or group of Aboriginal people and the land in terms of rights and interests is evident. Yet that is required by the NTA. The spiritual or religious is translated into the legal. This requires the fragmentation of an integrated view of the ordering of affairs into rights and interests which are considered apart from the duties and obligations which go with them. The difficulties are not reduced by the inevitable tendency to think of rights and interests in relation to the land only in terms familiar to the common lawyer.
}

With respect to the High Court there is nothing inherent in the concept of native title that leads ineluctably to such an outcome. Rather, it is the result of deliberate interpretative choices made by the Court itself, in particular the displacing of the centrality of the common law by the provisions of the Native Title Act. In contrast however, the CRO provisions of the Foreshore and Seabed Act are clearly drafted in the hope of ensuring a similar result. The language appears designed to force Māori to itemise claims, such that the outcome of an application to the Māori Land Court may be a $\mathrm{CRO}$ which is made up of a bundle of individual CRO-type rights, each of which relates to a physically manifested site-specific activity.

Whether these individualised, physicalised rights will be limited to domestic, personal consumption rights, or whether they could be broadened to include rights for exploitation, will depend on the Māori Land Court's interpretation of the criterion that the use, activity or practice be "integral" to tikanga Māori. The extent to which rights can evolve and to which non-personal

33 The Lardil Peoples $v$ State of Queensland, above n 31, para 7, 194 Cooper J.

34 The Lardil Peoples $v$ State of Queensland, above n 31, para 71 Cooper J.

35 Western Australia v Ward, above n 17, para 14 Gleeson CJ, Gaudron, Gummow and Hayne JJ. 
consumption rights can be recognised has proven a complex issue in both Australia and Canada. This issue is discussed below.

Further, of course, while the Foreshore and Seabed Act does not provide any real indication of what rights might be encompassed by a customary rights order, it does specify a number of activities which cannot be included. The most notable is that a customary rights order cannot include commercial or non-commercial fishing rights as covered by sections 9 and 10 of the Treaty of Waitangi (Fisheries Claims) Settlement Act 1992 or any activity, use or practice which is regulated by or under the Fisheries Act $1996 .{ }^{36}$ This latter exclusion has the potential to significantly narrow the range of rights that can be recognised. In addition, much wildlife and all marine mammals are excluded by section $49(1)(\mathrm{c}) .{ }^{37}$

\section{IV "INTEGRAL"}

Section 50(b)(i) of the Foreshore and Seabed Act requires that the "use, activity or practice" for which the applicant seeks a customary rights order "is, and has been since 1840, integral to tikanga Māori". Thus, it is not sufficient that it be shown that the use, activity or practice is tikanga Māori, but it must in addition be a use, activity or practice which is integral to tikanga. This begs the question, how does one distinguish between something "integral" and the rest, presumably peripheral?

The language of "integral" derives from the Canadian jurisprudence on aboriginal rights. In a trilogy of decisions in 1996 the Supreme Court of Canada developed a "test" in order to determine which existing aboriginal rights deserved protection under section 35(1) of the Constitution Act, $1982 .{ }^{38}$ Generally the need to identify rights which are "integral" arises in the situation where an accused pleads as a defence that the specific provision she or he has breached does not apply as they were exercising a constitutionally recognised aboriginal right. This almost always involves offences under resources legislation. Thus, almost all cases have involved hunting, fishing, the cutting of timber, or other site-specific practices. One exception is the decision in Pamejawon, which involved questions of self-government, and which is returned to shortly. ${ }^{39}$

36 Foreshore and Seabed Act, 2004, s 49(1)(a)(i) and (b). Sections 9 and 10 of the Treaty of Waitangi (Fisheries Claims) Settlement Act 1996 are considered to cover all fishing rights except "non-commercial fishing rights over species that are not subject to the Fishing [sic] Act": Te Arawa Mãori Trust Board v Attorney-General (5 December 2000) HC AK CP448-CO/99, S Anderson and Paterson JJ.

37 Foreshore and Seabed Act 2004, s 49(1)(c) excludes not only wildlife within the definition within section 2 of that Act, but also those animals specified in Schedule 6 of the Wildlife Act 1953. It also excludes any marine mammals which fall within the definition of marine mammal in section 2 of the Marine Mammals Protection Act 1978.

38 The leading decision is considered to be Van der Peet, above n 14; see also $R v$ Gladstone (1996) 137 DLR $\left(4^{\text {th }}\right) 648$ (SCC); Rv NTC Smokehouse (1996) 137 DLR $\left(4^{\text {th }}\right) 528$ (SCC).

$39 R$ v Pamajewon [1996] 2 SCR 821 (SCC). 
According to section 50(1)(b)(i), not only must the activity, use or practice be integral to tikanga Māori, but it must also have been integral since 1840. Thus, a connection is required between the activities, practices and acts undertaken today and those undertaken in 1840. How closely must the right claimed now be identifiable with activities, uses and practices undertaken 140 years ago? Can these activities and practices have evolved and changed, as they will inevitably have done as a response to the impact of colonialism? Or are Māori claimants limited to claiming essentially precontact practices? If it can be recognised that cultures evolve, change and adapt over time, to what extent can this have occurred? The same issues have arisen in both Canada and Australia and in both jurisdictions the courts' restrictive approaches to these questions have placed a significant limitation on the kind and extent of rights which have been recognised.

In Canada, the Supreme Court's approach, and the integral to the distinctive culture test, must be understood within the context in which it has arisen. This test is not designed to identify all traditional practices and cultures, but to identify those that deserve the protection of section 35(1) of the Constitution Act 1982. Thus, only those practices which are "core", or "central" to indigenous culture, are recognised as constitutionally protected aboriginal rights. Decisions involving section 35(1) are, in turn, influenced by the Court's understanding of the purpose of that section, which is, according to the Court, "[to reconcile] the prior occupation of North America by aboriginal peoples with the assertion of Crown sovereignty". ${ }^{40}$

According to Van der Peet, the "integral to the distinctive culture" test is ${ }^{41}$

directed at identifying the crucial elements of those pre-existing distinctive societies. It must, in other words, aim at identifying the practices, traditions and customs central to the aboriginal societies that existed in North America prior to contact with the Europeans.

In Pamajewon, L'Heureux-Dubé J stated practices are integral "if they are sufficiently significant and fundamental to the culture and social organization of a particular group of aboriginal people". ${ }^{42}$ They must be connected with the self-identify and self-preservation of the claimants' aboriginal society. ${ }^{43}$ Similarly, according to the majority in Mitchell the practice, custom or tradition must have been integral to the distinctive culture of the aboriginal people: ${ }^{44}$

40 Delgamuukw v British Columbia, above n 23, para 165 Lamer CJ, Cory and Major JJ; see also $R v$ Van Der Peet, above n 14, para 29-30 Lamer CJ, La Forest, Sopinka, Gonthier, Cory, Iacobucci and Major JJ; Haida Nation v British Columbia (Minister of Forests) (2004) 245 DLR $\left(4^{\text {th }}\right) 33$, 46 (SCC) McLachlin CJ for the Court; John Burrows "With You or Without You: First Nations Law (in Canada)" (1996) 41 McGill LJ 629.

41 Van der Peet, above n 14, para 44 Lamer CJ, La Forest, Sopinka, Gonthier, Cory, Iacobucci and Major JJ.

$42 R v$ Pamajewon, above n 39, para 39 L'Heureux-Dubé J.

$43 R$ v Pamajewon, above n 39, para 39 L'Heureux-Dubé J.

44 Mitchell v Minister of National Revenue [2001] 1 SCR 911, para 12 McLachlin CJ Gonthier, Iacobucci, Arbour and LeBel JJ. 
$\ldots$ in the sense that it distinguished or characterized their traditional culture and lay at the core of the aboriginal people's identity. It must be a "defining feature" of the aboriginal society, such that the culture would be "fundamentally altered" without it. It must be a feature of "central significance" to the peoples' culture, one that "truly made the society what it was" (Van der Peet, supra, at paras. 54-59 (emphasis in original)). This excludes practices, traditions and customs that are only marginal or incidental to the aboriginal society's cultural identity, and emphasizes practices, traditions and customs that are vital to the life, culture and identity of the aboriginal society in question.

The most problematic aspect of deciding whether a practice is "integral" arguably lies in determining the extent to which traditional defining features of a society can have changed in response to the impact of colonialism and yet still be integral. ${ }^{45}$ The connection between pre-contact practices and modern activities, which underpins the "distinctive to the integral culture test", as well as the "integral" requirement in the Foreshore and Seabed Act, means that the approach taken to characterising the modern right is crucial. Obviously, what can be recognised depends on the approach taken to the initial characterisation. Generally characterisation begins with the modern rights, and seeks to not only find a similar set of practices rooted in the past, but also to show that these practices were integral or central to the distinctive culture of the group. By starting with the modern right and then trying to find evidence of that right being practiced in the past, it is almost guaranteed that the claim will fail. As Brad Morse has stated, the exercise becomes "a judicial assessment of historical, sociological and anthropological evidence of what constitutes an integral, central, significant, defining or distinctive part of a culture that was freeze-dried at the time of contact with Europeans". ${ }^{46}$

In the original trilogy of Van der Peet, Gladstone and NTC Smokehouse, appellants all claimed an aboriginal right to commercially exploit herring spawn on kelp. In Gladstone, the accused, members of the Heiltsuk Band, invoked section 35(1) as a defence to offences involving the sale of herring spawn on kelp in contravention of the British Columbia Fishery Regulations. In effect, the appellants argued that they had an aboriginal right to commercially exploit herring spawn on kelp, that aboriginal right taking the specific form of the right to sell the spawn. In that case the majority accepted that commercial trade in herring spawn on kelp was an integral part of the distinctive culture of the Heiltsuk prior to contact and was not merely incidental to social or ceremonial activities. However, in that case there was "extensive evidence of historical trading of herring spawn on kelp between the Heiltsuk and the neighbouring aboriginal peoples. The trade that took place was on a large scale, involving quantities of herring spawn on kelp of at least 15 tonnes". ${ }^{47}$ In effect, therefore, the Court did not allow for evolution of rights, but rather held that there was evidence of

45 See "Frozen Rights in Canada", above n 16, 7.

46 Brad Morse "Permafrost Rights: Aboriginal Self-government and the Supreme Court in $R v$ Pamajewon" (1997) 42 McGill LR 1011, 1031.

$47 R v$ Gladstone, above n 38, para 161 McLachlin J. 
commercial activity pre-contact. In the other two cases involving almost identical facts the accused were unable to show similar evidence, and failed.

Similar narrow outcomes were achieved in the decisions in Pamajewon and Mitchell. In Pamejawon the accused, Pamajewon and Jones, were charged with the offence of keeping a common gaming house, contrary to the Ontario Criminal Code. Pamejawon and Jones were members of the Shawanaga First Nation. The Nation had been undertaking gambling operations, including high stakes gambling with regular and "monster" jackpots on the Band's reserve. Pamejawon and Jones claimed an aboriginal right of self-government, or a right to manage the use of their reserve lands, which was protected by section 35(1). However, the majority of the Supreme Court preferred to characterise it as "the rights of the Shawanaga and Eagle Lake First Nations to participate in, and to regulate, gambling activities on their respective reserve lands". ${ }^{48}$

Evidence was presented at trial that gaming was prevalent in Ojibway culture, but they did not accept that it was of central significance as required by the "integral to the distinctive culture" test. Further, there was no evidence that historically the community had regulated gaming. Finally, the large scale activities undertaken were contrasted with the small-scale gaming of the past. ${ }^{49}$ Thus, the participation in, and regulation of, gambling could not be the modern form of traditional gaming, nor was that traditional gaming a defining characteristic of Ojibway culture. Had the Supreme Court been prepared to characterise the right as a right to manage use of reserve lands the outcome may have been quite different. Gambling then would only be an example of the broader right and it would presumably have been unnecessary to show that high-stakes gambling itself was "integral".

In Mitchell, the issue was whether the Mohawk Canadians of Akwesasne had an aboriginal right to bring goods into Canada from the United States for collective use and non-commercial trade with other First Nations without paying customs duties. The Akwasasne are a Mohawk community, once part of the Mohawk Nation whose territory spanned the United States/Canadian border. Chief Mitchell characterised his claim as the right to enter Canada with personal and community goods and trade with First Nations in Quebec and Ontario. The majority characterised it more broadly as "the right bring goods across the St Lawrence River to trade". It was held that while there was "ample evidence" to support a finding that trade was a central, distinguishing feature of the Mohawk, it did not establish an ancestral Mohawk practice of transporting goods across the St Lawrence River for trade. ${ }^{50}$ While there was evidence of trade on an east-west axis, there was little, if any, of trade on a north-south axis. In fact the possibility of such trade was precluded by warfare

$48 R v$ Pamajewon, above n 39, para 26 Lamer CJ, La Forest, Sopinka, Gonthier, Cory, McLachlin, Iacobucci and Major JJ.

$49 R$ v Pamajewon, above n 39, para 28 Lamer CJ, La Forest, Sopinka, Gonthier, Cory, McLachlin, Iacobucci and Major JJ.

50 Mitchell $v$ Minister of National Revenue, above n 44, paras 41, 42 McLachlin CJ Gonthier, Iacobucci, Arbour and LeBel JJ. 
between the Five Nations and their northern neighbours. ${ }^{51}$ Even had evidence of north-south trading been accepted, it was not a defining feature of Mohawk culture. ${ }^{52}$

Similar issues have faced the High Court of Australia, although there is no "integral to the distinctive culture test". The High Court has constantly reiterated that aboriginal laws and customs are dynamic, rather than static. However, that Court's approach has been to require a direct correlation between modern practices and those that were undertaken pre-sovereignty. The effects of colonialism and the impact of white culture are rarely taken into account, with the result that in practice virtually no real evolution or change has been accepted. In Yorta Yorta, the trial judge, Olney J, held that the Yorta Yorta people had failed to prove the required continuing observance of traditional laws and customs. He characterised their fishing practices as for "recreation", rather than "subsistence", and therefore "not the continuation of a traditional custom". ${ }^{53}$ Similarly, in Daniel $v$ Western Australia, Nicholson $\mathrm{J}$ stated that the applicants "from time to time ... build shelters (including boughsheds, mias (may as) and humpies) and live there. I do not consider the evidence establishes the activity extends to building houses other than shelters. ${ }^{54}$ Probably the best known comment in relation to this matter is that of Callinan $\mathrm{J}$ in Yorta Yorta. While his Honour does not deny that change can occur, he stated that: ${ }^{55}$

The matter [of how far custom may evolve] went uncontested in Yanner v Eaton, although for myself I might have questioned whether the use of a motorboat powered by mined and processed fuel, and a steel tomahawk, remained in accordance with a traditional law or custom, particularly one of alleged totemic significance.

Both the "integral to the distinctive culture" test in Canada, and the approach taken by the High Court of Australia to the question of evolution of rights, has placed considerable limitations on the rights which can be recognised in those jurisdictions. Almost no allowance is made for the dynamic nature of culture, or its evolution in response to new circumstances and external influence. The "ossifying" effect of the integral test in Canada, as well as the incompatibility of such an approach with the Treaty of Waitangi, was specifically noted by Paul McHugh in his evidence to the Waitangi Tribunal on the foreshore and seabed policy. ${ }^{56}$ Despite this acknowledgement, the requirement remained in the final form of the legislation. Nevertheless, there is reason to hope that the outcomes

51 Mitchell $v$ Minister of National Revenue, above n 44, para 44 McLachlin CJ Gonthier, Iacobucci, Arbour and LeBel JJ.

52 Mitchell v Minister of National Revenue, above n 44, para 54 McLachlin CJ Gonthier, Iacobucci, Arbour and LeBel JJ.

53 Yorta Yorta (FCA), above n 19, para 123 Olney J.

54 Daniel v Western Australia [2003] FCA 666, para 260.

55 Members of the Yorta Yorta Community v Victoria, above n 15, para 187 Callinan J.

56 Report on the Crown's Foreshore and Seabed Policy, above n 20, 57. 
in New Zealand will be of a different quality. While the peak courts in Canada and Australia decry the Western law focus of their inquires, or purport, in the case of the Canadian Supreme Court, to judge matters from both the Western and Aboriginal perspectives, the Māori Land Court is unique in its understanding of, and ability to proceed from, tikanga Māori. While the legislation does require some connection to be made between the practices of 1840 and the practices of the modern day, any approach which equates modern practices with those of 1840 is unnecessarily restrictive and, as the Waitangi Tribunal noted in its report, would be inconsistent with the Tribunal's "acceptance of a Māori right of development, including the use of technology unknown in 1840 ...". 57

Section 52 of the Foreshore and Seabed Act provides for rights under CROs to be protected as "recognised customary activities" under the Resource Management Act 1991 (RMA). ${ }^{58}$ In particular, section 52(2) states that a CRO may entitle the whānau, hapū or iwi on whose behalf the order is made to derive a commercial benefit from activities undertaken in pursuance of the CRO. This is limited, however, by section 52(3), which further provides that:

However, the exercise of any recognised customary activity, whether or not a commercial benefit is derived from carrying out the activity, is subject to the scale, extent, and frequency specified for the recognised customary activity in the customary rights order.

To the extent that the exercise of an activity exceeds the scale, extent or frequency specified in the CRO the activity will not be protected as a "recognised customary activity" under the RMA. ${ }^{59}$ There are two possible interpretations of this provision. The first, and possibly more cynical, is that specifically limiting commercial possibilities to the breadth of the CRO order virtually ensures that little or no commercial activity will be possible given the narrow drafting of the CRO provisions themselves. One may argue that it will be difficult for the Māori Land Court to make an order which includes commercial rights without straining the wording of the legislation itself and section 52(3) makes it clear that unless this occurs, no commercial benefits are possible. The other interpretation is that section 52 specifically allows for commercial activity, recognises that CROs may be made which include commercial rights, and simply provides for the protection of such rights under the RMA. Obviously, if CROs are to deliver any real outcomes for Māori claimants then section 52 should be read as recognising the possibility of commercial scale rights.

57 Report on the Crown's Foreshore and Seabed Policies, above n 20, 58 referring to Waitangi Tribunal Report of the Waitangi Tribunal on the Muriwhenua Fishing Claim (Wai 22, Wellington, 1988); and Waitangi Tribunal The Ngai Tahu Sea Fisheries Report (WAI 27 Brooker and Friend, Wellington, 1992).

58 Resource Management Act 1991. according to section 2, a "recognised customary activity" is anything recognised under a customary rights order under the Foreshore and Seabed Act 2004.

59 Foreshore and Seabed Act 2004, s 52(4). 


\section{V "SUBSTANTIALLY UNINTERRUPTED"}

In addition to being "integral", the legislation also requires that the activity, use or practice have been carried on, exercised, or followed in accordance with tikanga Māori in a substantially uninterrupted manner since $1840 .{ }^{60}$ The requirement that the uses, practices and traditions which are relied on to found aboriginal rights/title be substantially uninterrupted is a facet of both Australian and Canadian aboriginal title doctrine. However, just what is meant by this requirement has proven complex, particularly in the Australian context. In Australia "substantially uninterrupted" is really part of the requirement that there be an "on-going connection with the land". This is a requirement that has proven controversial in practice because of the widespread dislocation of Indigenous Australians which occurred in colonial Australia. Peoples were frequently relocated, removed from, and locked out of, their country. This has made it difficult for some to meet the requirement of a continuing connection. Such problems have been exacerbated by the restrictive approach taken by the High Court to this issue, particularly with respect to the effect of forcible removals. The onus is on the claimants to demonstrate that they have not ceased to maintain a connection to the land. Further, the requirement of connection to the land does not take into account forcible removal of Indigenous Australians from their land nor the dislocating effects of European culture. In fact, in most cases forcible removal will result in a loss of connection, and hence inability to prove native title. The High Court has held that physical occupation of the land is not a requirement to prove on-going connection, as by "continuing to acknowledge and observe traditional laws and customs involving ritual knowledge, ceremony and customary practices, the spiritual relationship to the land can be maintained." ${ }^{61}$ However, it is difficult to point to a case in which it has not been held that connection was lost because of physical dislocation. The Federal Court decision in De Rose v South Australia is a good example. ${ }^{62}$ In that case, O'Loughlin J held that the claimant group had failed to show a continuing connection after 1978 as they had not proven continuing acknowledgement of traditional laws, particularly in the form of rituals and ceremonies. In 1978 the claim group had been forced to leave the pastoral station which was located on their traditional country as there was no work and because of the conduct of the pastoral operator. They were held to have lost their connection, despite the recent nature of the physical loss of connection and the reasons for it.

While the courts in Canada and Australia are still grappling to define the circumstances in which practices and traditions have been substantially interrupted, section 51(1) of the Foreshore and Seabed Act specifies that an activity, use or practice has not been substantially uninterrupted if it "has been or is prevented from being carried on, exercised, or followed by another activity

60 Foreshore and Seabed Act 2004, s 50(1)(b)(ii). Emphasis added.

61 Western Australia v Ward, above n 17, para 252 Gleeson CJ, Gaudron, Gummow and Hayne JJ.

62 De Rose v South Australia [2002] FCA 1342. 
authorised by or under an enactment or rule of law". If this is the case, the claimant will have failed to establish that the activity, use or practice can be the subject of a CRO. This provision removes certain activities from the "factual matrix"63 which is established at the proof stage. ${ }^{64}$ In effect, section 51(1) imports an extinguishment step into that proof stage. The words "another activity" make it clear that it is the fact of the activity which renders it legally impossible to show that an activity, use or practice was substantially uninterrupted since 1840. Presumably, any activity for which resource consent has been given would fall into this category. For example, physical interruption caused to gathering activities by the building of a jetty, or undertaking of aquaculture activities may qualify. Further, section 51(1) leaves unanswered the question of what level of interference is required before an activity, use or practice "has been or is prevented from being carried on, exercised or followed". Given the extraordinarily draconian nature of this provision, it should be interpreted strictly, and only those activities which constitute an actual prevention should trigger its operation.

\section{VI "IS NOT PROHIBITED BY ANY ENACTMENT OR RULE OF LAW"}

The final step of the "proof stage" is that the activity, use or practice must not be "prohibited by any enactment or rule of law". ${ }^{65}$ Again, if an activity, use or practice has been prohibited then it is effectively removed from the "factual matrix". Thus, section 50(1)(b)(iv) of the Foreshore and Seabed Act layers another hurdle onto that in section 51(1) and imports a second extinguishment step into the proof stage. The phrase "enactment or rule of law" is broad. It covers not only legislation and regulations, but the common law or equity. Thus, regulatory prohibitions on takings under conservation legislation are potentially caught by this subsection.

This subsection may forestall the on-going debate before both Canadian and Australian courts as to whether regulation can amount to extinguishment. Both the High Court of Australia and the Supreme Court of Canada have held that a distinction must be drawn between acts which regulate, and those which extinguish, customary rights. ${ }^{66}$ Living resource legislation can affect customary rights by requiring licensing, setting catch or gear restrictions, or banning hunting and fishing of certain species. While fisheries have been effectively excluded from the ambit of the CRO, rights to take non-protected wildlife may be the subject of a CRO. The problem lies in determining when a law or regulation affects customary rights to such an extent that they are considered extinguished. In Yanner, Gummow J suggested that: ${ }^{67}$

63 "From Common Law to Codification ", above n 6, 31.

64 There has been some debate in Australia as to whether "loss of connection" is an extinguishing event, or whether it is part of the factual matrix surrounding proof of native title.

65 Foreshore and Seabed Act 2004 s 50(1)(b)(iv).

66 See Yanner v Eaton (1999) 166 ALR 258 (HCA).

67 Yanner v Eaton, above n 66, para 109 Gummow J. 
Factual findings are necessary to establish the ambit of the native title right as defined by the traditional laws and customs of the indigenous community. The ambit of the native title right is a finding of law. This must then be placed against the statutory rights which are said to abrogate it. The question to be asked in each case is whether the statutory right necessarily curtails the exercise of the native title right such that the conclusion of abrogation is compelled, or whether to some extent the title survives, or whether there is no inconsistency at all. Indeed, the statute may regulate the exercise of the native title right without in any degree abrogating it.

The problems of making such a determination can be seen in the Australian case of Ward. At both first instance, and in the Federal Court of Appeal, it was held that certain by-laws which prohibited interference with flora and fauna were a regulation, rather than an extinguishment of native title. ${ }^{68}$ In the High Court the effect of these by-laws was directly discussed by Callinan J, who stated that: 69

The regulations are extraordinarily comprehensive: they purport to make unlawful any interference in any way with the natural environment, whether by lighting fires, by disturbing vegetation, or even by disturbing leaf mould. No native title right could, in my opinion, be meaningfully or usefully exercised consistently with the catalogue of prohibitions. Indeed, it is significant that neither the Full Court nor the claimants have attempted to identify any possible surviving native title. The regulations extinguish native title in entirety.

The issue of the effect of regulation on aboriginal rights has also been the subject of some examination by the Supreme Court of Canada. As outline earlier, section 35(1) of the Constitution Act 1982, "protects and affirms" "existing aboriginal rights". Thus, any examination of whether claimed rights are constitutionally affirmed also includes an examination of whether, in order to be "existing rights" those rights remained unextinguished in 1982. Given that the majority of section 35(1) cases have involved defences to alleged infringements of resources legislation, the question of whether resource regimes have extinguished aboriginal rights has been before the Supreme Court of Canada on a number of occasions. While their Honours generally agree that regulating the use of a resource does not amount to extinguishment, the question still remains as to when regulation become so stringent that it amounts to extinguishment. In general, as one might expect, that Court has exhibited a more generous interpretation of the regulation/extinguishment distinction than the High Court of Australia.

In Gladstone, two sets of regulations were at issue. The first purported to generally limit aboriginal rights to fish to subsistence rights. The second related to a particular fishery - the herring spawn on kelp fishery - and provided that no person could take, collect, buy, sell or barter herring

68 Ward v Western Australia (1998) 159 ALR 483, 583 Olney J (FCA); Western Australia v Ward (2000) 170 ALR 159, para 406 (FFC) Beaumont and von Doussa JJ.

Western Australia v Ward, above n 17, para 787 Callinan J. 
eggs, but that an Indian may at may time do so for subsistence purposes. ${ }^{70}$ The majority held that neither set of regulations extinguished the aboriginal right at issue, as there was no plain and clear intention to do so. ${ }^{71}$ Rather, the purpose of the Regulation was to ensure that conservation goals were met so that salmon reached their spawning grounds in the upper parts of the river, and to ensure the special protection of the Indian subsistence food fishery. ${ }^{72}$ The purpose was not to eliminate aboriginal rights to fish commercially. Thus, the failure to recognise an aboriginal right, here the right to fish commercially, and the failure to grant special protection to it, do not constitute a clear and plain intention to extinguish. ${ }^{73}$ Similarly, McLachlin J held that a measure aimed at the conservation of a resource is not inconsistent with a recognition of an aboriginal right to make use of that resource and thus did not extinguish it. The prohibition on possessing herring spawn on kelp was a conservation measure and did not extinguish the aboriginal right at issue. ${ }^{74}$ L'Heureux-Dubé $\mathrm{J}$ was of the opinion that in order to extinguish, the government must directly address the aboriginal activities in question and explicitly extinguish them by making them no longer permissible. ${ }^{75}$ She also rejected the argument that the plain and clear intention test is met when the aboriginal right and activities contemplated by the legislation cannot co-exist. ${ }^{76}$ In other words, her Honour rejected the Australian approach.

As regards the second set of regulations at issue in Gladstone, the majority again found that these did not extinguish the aboriginal right at issue as they failed to express a clear and plain intention to extinguish the Heiltsuk Band's rights. The legislative history revealed that at various times aboriginal peoples had been entirely prohibited from harvesting herring spawn on kelp, had been allowed to harvest for food only, had been allowed to harvest with written permission, and had been allowed to harvest for food with a licence. Such an inconsistent and varied scheme did not express a clear and plain intention. ${ }^{77}$ Thus, total prohibition of an activity does not extinguish it.

Ultimately, therefore, the Foreshore and Seabed Act forestalls the debate on the effect of regulation on customary rights and takes the much stricter Australian position that regulation amounting to prohibition constitutes extinguishment. Thus, where an activity is prohibited the activity, use or practice is removed from the factual matrix which constitutes the basis of a CRO.

70 British Columbia Fishery Regulations SOR/54-659, s 21A.

71 The majority in this case was composed of Lamer CJ, Sopinka, Gonthier, Cory, Iacobucci and Major JJ.

$72 R v$ Gladstone, above n 38, 666 Lamer CJ, Sopinka, Gonthier, Cory, Iacobucci and Major JJ.

73 La Forest J specifically dissented on this point: $R v$ Gladstone, above $\mathrm{n} 38,697$.

$74 R v$ Gladstone, above n 38, 713 Lamer CJ, Sopinka, Gonthier, Cory, Iacobucci and Major JJ.

$75 R v$ Gladstone, above n 38, 707 Lamer CJ, Sopinka, Gonthier, Cory, Iacobucci and Major JJ.

$76 R v$ Gladstone, above n 38, 707 Lamer CJ, Sopinka, Gonthier, Cory, Iacobucci and Major JJ.

$77 R v$ Gladstone, above n 38, 664 Lamer CJ, Sopinka, Gonthier, Cory, Iacobucci and Major JJ. 
Finally, it should be noted that the subsection refers to an activity, use or practice which is (singular) prohibited. Thus, if CROs are a collection or bundle of non-territorial rights, this subsection presumes that sticks in the bundle can be selectively extinguished. In other words, prohibiting a particular activity will eliminate that activity from the factual matrix, leaving the others intact. This is a similar approach to that taken by the Australian High Court on partial extinguishment in Ward and Yorta Yorta. This is, however, particularly concerning, as the High Court's approach to partial extinguishment, as briefly discussed in the next section, derives in the main from the provisions of the Native Title Act 1993 (Cth), not primarily from the common law.

\section{EXTINGUISHMENT}

Once evidence has been brought to show the content of the rights claimed, and that the rights have been exercised in a substantially uninterrupted manner since 1840, an examination must then be made to ensure that the rights have not been extinguished. As a prerequisite to the granting of a CRO, the Māori Land Court must be satisfied that the right to carry on, or follow the activity, use or practice has not been extinguished as a matter of law. ${ }^{78}$ This requirement is layered onto the other extinguishment tests (discussed above) which are designed to remove certain rights from the factual matrix which can constitute a CRO.

Section 51(2) provides further clarification of what constitutes extinguishment for the purposes of section 50(1)(c). In particular, section 51(2)(a) and (c) provide that the right to carry on activities, uses or practices, which are in turn to be relied upon to establish customary rights, have been extinguished where: ${ }^{79}$

(a) legal title has been vested by any means in a person or group other than the whānau, hapū or iwi on whose behalf the order is sought ...; or

(c) an interest has been established that is legally inconsistent with the activity, use, or practice for which the customary rights order is sought.

It is the issue of extinguishment on which the Ngati Apa court gave the most guidance as to how a common law doctrine of aboriginal title might look in New Zealand. Keith and Anderson JJ held that, as in the United States and Canada, the standard for extinguishment is that any intention to so do must be clear and plain. ${ }^{80}$ Further, the onus is on the Crown to show that there is a clear and plain intention to extinguish. ${ }^{81}$ Their Honours went on to confirm, for example, that the vesting of title to the territorial sea, contiguous zone and exclusive economic zone in the Crown by legislation

78 Foreshore and Seabed Act 2004, s 50(1)(c).

79 The third sub-section, 51(2)(b) confirms an activity, use or practice will have been extinguished by a lawful reclamation of the relevant part of the foreshore or seabed.

80 Attorney-General v Ngati Apa, above n 5, para 148 Keith and Anderson JJ.

81 Attorney-General v Ngati Apa, above n 5, para 148 Keith and Anderson JJ. 
did not extinguish, as there was no clear and plain legislative intention to so do. ${ }^{82}$ Keith and Anderson JJ also use the language of inconsistency, albeit in a passing reference, while Elias CJ confirmed that the grant of a freehold title would extinguish any pre-existing Māori customary property interest with which it was inconsistent. ${ }^{83}$ She went on to say that: ${ }^{84}$

Whether any such [customary] interests have been extinguished is a matter of law. Extinguishment depends on the effect of the legislation and actions relied upon as having that effect.

As is the case with the common law test in Australia, and in keeping with the above comments by Elias CJ, the extinguishment provisions contained in section 51(2) of the Foreshore and Seabed Act emphasise that it is legal interests, rather than factual circumstances which extinguish customary rights. ${ }^{85}$ Section 51(2) provides a (non-exhaustive) list of ways in which legal title may have been vested in relation to the area of the foreshore and seabed in the application, thus extinguishing the activity, use or practice on which the application is based. These include Crown grant, common law, statutory vesting or administrative action. It is accepted in overseas jurisdictions that extinguishment can occur because of either Crown grant or statutory vesting. However, the references to common law and administrative action are, as McHugh has commented, "mysterious". ${ }^{86}$ In particular, the reference to "administrative action" is concerning. Most administrative action which is accepted in other jurisdictions to extinguish native title should be caught already by the provision that Crown grants extinguish customary rights. This subsection, if interpreted liberally, could allow the Crown to extinguish by administrative action in a wide range of situations which would not amount to extinguishment at common law.

One particular issue which has been left unclear in the legislation is the meaning of "legal title". As any property lawyer knows, legal title simply means a title recognised at law, and could apply to a variety of interests. At common law, it is the quality of the interest and the rights conferred by it, which extinguishes native or aboriginal title, not the fact that it is a legal interest per se. Thus, a freehold estate extinguishes native title, ${ }^{87}$ because it confers exclusive possession. An interest which

82 Attorney-General v Ngati Apa, above n 5, para 162 Keith and Anderson JJ.

83 Attorney-General v Ngati Apa, above n 5, para 161 Keith and Anderson JJ, para 58 Elias CJ. Attorney-General v Ngati Apa, above n 5, para 49 Elias CJ.

85 See Wik Peoples v Queensland (1996) 187 CLR 1, extinguishment by factual circumstance is, however, as indicted above, provided for in Foreshore and Seabed Act 2004, ss 50(1)(b)(iv) and 51.

86 "From Common Law to Codification", above n 6, 28. It is unclear what is comprehended by "common law". One possibility is adverse possession. While no claim can now be brought for adverse possession of a foreshore area (s 24) any claim previously made and finalised would presumably be covered by either section 51(2)(a)(ii) "common law" or 51(2)(a)(iv) "administrative action" (covering the transfer of title to the adverse possessor).

87 As confirmed Elias CJ in Attorney-General v Ngati Apa, above 5, para 58. 
confers less than exclusive possession only extinguishes to the extent of the inconsistency between the rights conferred by the title and the customary rights (see below). This begs the question, if according to section 51(2)(a)(i) a Crown grant which confers legal title extinguishes customary rights does this Crown grant have to be one which confers exclusive possession? Will a legal interest which confers a lesser degree of possession suffice? Even if it were determined that a legal interest conferring less than exclusive possession, for example a licence, does not extinguish, it may be that the activities carried on under that licence, for example aquaculture, would be considered sufficient to have prevented the undertaking of customary activities, and therefore to have effectively extinguished them in any case under section 51(1) by taking them out of the factual matrix. In combination, section 51(1) and (2) potentially create a more draconian extinguishment regime than exists in either Canada or Australia. Much will depend on the evidentiary threshold levels established by the courts in relation to these provisions.

Finally, section 51(2)(c) provides that an activity, use or practice will be extinguished if an interest has been established with which it is legally inconsistent. This seems to be a "catch-all" provision, as it is hard to imagine what interests could fall under this section that would not already have been covered by section 51(2)(a). The Foreshore and Seabed Act has no definition of legally inconsistent. While the notion of "legally inconsistent" may appear straightforward, it has not always proved to be so in Australia. Although interests which establish rights of exclusive possession are considered to be legally inconsistent, ${ }^{88}$ the Australian High Court has developed a significant jurisprudence with respect to lesser interests, in other words those which do not necessarily carry exclusive possession.

The test for extinguishment, generally known as the "inconsistency test" originally derives from the Native Title Act, as refined in subsequent decisions, particularly that of the Wik Peoples and Ward. In the Native Title Act Case it was explained that: ${ }^{89}$

After sovereignty is acquired, native title can be extinguished by a positive act which is expressed to achieve that purpose generally... provided the act is valid and its effect is not qualified by a law which prevails over it or over the law which authorises the act. Again, after sovereignty is acquired, native title to a particular parcel of land can be extinguished by the doing of an act that is inconsistent with the continued right of Aborigines to enjoy native title to that parcel - for example, a grant by the Crown of a parcel of land in fee simple - provided the act is valid and its effect is not qualified by a law which prevails over it or over the law which authorises the act.

This was known as extinguishment by necessary implication, and came to be the basis of the "inconsistency" test for extinguishment. As the majority judgment stated in Ward: ${ }^{90}$

88 Wik Peoples $v$ Queensland, above n 85; Fejo v Northern Territory, above n 13.

89 Western Australia v The Commonwealth (The Native Title Act Case) (1995) 183 CLR 373, 422 (HCA) Mason CJ, Brennan, Deane, Toohey, Gaudron and McHugh JJ. 
the ultimate question is whether, by the steps that were taken, the Crown created in others, or asserted, rights in relation to the land that were inconsistent with native title rights and interests over land.

Thus, the key is whether the enactment, grant or executive action authorised by legislation created an interest, the legal character of which is inconsistent with the continued existence of the native title interest. It is not a question of whether the actual use of land is inconsistent with the continued existence of those native title rights and interests. Thus, the grant of an estate in fee simple will extinguish native title, as it confers exclusive possession which is entirely inconsistent with the continued existence of native title, while a pastoral lease, which does not confer exclusive possession, will only extinguish to the extent of the inconsistency. This is regardless, in both cases, of whether the land was ever actually used, or even whether the interest still exists.

In Ward, the High Court took the issue of extinguishment one step further, by determining that in some cases partial extinguishment was possible. In part this follows from the Court's characterisation of the native title as a "bundle of rights" and in part from their decision that the extinguishment framework of the Native Title Act mandates partial extinguishment. ${ }^{91}$ Thus, selected "sticks" in the bundle of rights can be extinguished by inconsistent interests, thereby leaving other sticks intact. The effect will be "piecemeal erosion of native title". ${ }^{92}$ The Foreshore and Seabed Act has, as indicated above, accepted that customary rights can be conceptualised as a "bundle of rights", and appears, as also indicated above, to have opened the door for arguments of partial extinguishment. This is a particularly unfortunate borrowing from Australian jurisprudence, as there is no recognition that both the "bundle of rights" and partial extinguishment aspects of native title law derive from the statutory regime of the Native Title Act, not the common law.

Section 51 arguably incorporates a greater range of extinguishing events than would be aknowledged at common law in either Australia or Canada. There is in addition considerable overlap between both the provisions in section 51(2) and (3), as well as with the earlier provisions which are designed to remove rights from the factual matrix. As a direct result of the inclusion of section 51(2)(c), and as further result of the fact that it is unclear in what circumstances some of the subsections in 51(2)(a) are intended to operate, the common law test for extinguishment may provide an important guide to interpreting this provision. However, once again, given the statutory rather than common law jurisdiction of the Māori Land Court with respect to CROs, it is open to the

90 Western Australia v Ward above n 17, para 214 Gleeson CJ, Gaudron, Gummow and Hayne JJ.

91 The Court held that Part 2, Div 2 and 2B of the Act formed a statutory framework for extinguishment. In particular, sections 11 and 15 confirm the complete or partial extinguishment of native title by past acts such as the grant of freehold or exclusive possession leasehold, or by previous exclusive possession acts and previous non-exclusive possession acts under section 23C and section 23G: Western Australia v Ward, above n 17, para 9 Gleeson CJ, Gaudron, Gunnow and Hayne JJ.

92 Lisa Strelein "Western Australia v Ward on behalf of Miriuwung Gajerrong, High Court of Australia, 8 August 2002: Summary of Judgment" (2002) 2 Land, Rights, Laws: Issues of Native Title 1, 2. 
Māori Land Court (as it is to any court) to forge its own jurisprudence, regardless of the common law standards.

\section{CUSTOMARY RIGHTS ORDERS: HOW BROAD CAN THE RECOGNISED RIGHTS BE?}

Finally, it is interesting to speculate, albeit very briefly, about how wide a CRO could be. The first claim lodged, by the Whakatohea of Eastern Bay of Plenty, seeks to maximise claims that can be made under the legislation by including claims for kaitiakitanga and rangatiratanga. Kaitiakitanga is defined in the Act as having the same meaning as in section 2(1) of the RMA.93 Section 2(1) states that "[k]aitiakitanga means the exercise of guardianship by the tangata whenua of an area in accordance with tikanga Māori in relation to natural and physical resources; and includes the ethic of stewardship". Thus, its definition already includes several elements that are required to be proven in order to obtain a CRO. In particular, the activity, use or practice must be exercised in accordance with tikanga Māori. ${ }^{94}$

Tikanga is defined in Te Ture Whenua Māori Act 1993 as "Māori customary values and practices". ${ }^{95}$ However, as the Waitangi Tribunal has pointed out, this is "an arid, Eurocentric" analysis. ${ }^{96}$ In contrast, in the Report on the Crown's Foreshore and Seabed Policy, the Waitangi Tribunal said of tikanga that: ${ }^{97}$

... everything is about tikanga, and tikanga is about everything. In the traditional Māori worldview, there is no matter that does not have tikanga attached to it. And the foreshore and seabed - te takutai moana, te papamoana - are quintessentially bound up with tikanga. Tikanga imbues consideration of every aspect of the elements themselves, and how humans interact with them.

While there is obviously no exact parallel from other jurisdictions to a claim for kaitiakitanga and rangatiratanga, in Canada First Nations peoples have claimed that the doctrine of aboriginal rights should include self-government. While self-government has not been explicitly recognised by the Supreme Court of Canada as part of the doctrine of aboriginal rights, it has been implicitly recognised. ${ }^{98}$ Most importantly, the Supreme Court has not taken several opportunities presented to

93 Foreshore and Seabed Act 2004, s 5.

Foreshore and Seabed Act 2004, s 50(1)(b)(i); also a CRO can be made on the basis of a spiritual association if that association is manifested in a physical activity, use or practice related to a natural or physical resource, s 49(2).

95 Te Ture Whenua Māori Act 1993, s 3.

Report on the Crown's Foreshore and Seabed Policy, above n 20, 1.

97 Report on the Crown's Foreshore and Seabed Policy, above n 20, 1. 
it to hold that there is no inherent right of self-government. ${ }^{99}$ Most recently, in Campbell, a decision of the British Columbia Supreme Court, Williamson J accepted that the inherent right to selfgovernment was part of the doctrine of aboriginal rights. ${ }^{100}$ In that case, the plaintiffs, three members of the Parliament of British Columbia brought an action seeking to have the court strike down several provisions of the Nisga'a Treaty on the grounds that it bestowed upon the Nisga'a Nation a legislative jurisdiction which was inconsistent with the exhaustive division of powers in the Constitution between federal and provincial governments. However, Williamson J held that the Aboriginal peoples of Canada had legal systems prior to the arrival of Europeans and that these legal systems, albeit diminished, continued after contact. ${ }^{101}$ As a result, self-government was a right protected by section 35(1) of the Constitution Act 1982.

Logically, there is no reason why kaitiakitanga in particular could not be characterised as a practice and, as long as on the facts the criteria required by section 50 and 51 for a CRO were made out, could not be the subject of a CRO. Such an argument would require evidence to be adduced which demonstrated the physical manifestation of kaitiakitanga in relation to a physical or natural resource. While the nature of this relation varies from region to region, as the Waitangi Tribunal has noted, tikanga (which includes kaitiakitanga) has both spiritual and physical dimensions. ${ }^{102}$ Similarly, evidence would need to be brought to demonstrate that kaitiakitanga was and is integral to tikanga Māori, and has been since 1840. Presumably, for many whānau, iwi and hapū this would present little difficulty. Ironically, the criterion of "substantially uninterrupted", intended as a limiting factor, becomes less difficult to establish the broader the right claimed. The continuing centrality of tikanga to many Māori means that a wide range of activities and practices could be drawn upon evidentially to prove a claim to kaitiakitanga. While certain activities or practices cannot be the subject of a CRO, there is no reason to suppose that they cannot be used as evidence of a wider right. For example, while matters which are regulated under the Fisheries Act 1996 cannot be included within a $\mathrm{CRO},{ }^{103}$ there is no reason why such matters could not go to show a broader right.

If sufficient evidence can be brought on which a CRO could be based, the next stage would be to consider whether the right has been extinguished. Ironically, while the extinguishment provisions are extensive, they are also drafted under an assumption that the rights contained in a CRO are

99 In $R v$ Delgamuukw, above n 23, for example, the Supreme Court of Canada did not take the opportunity to confirm self-government, although as has been noted by commentators, it also directly did not take the opportunity to state that there was not such a right: Kent McNeil "Self-Government and the Inalienability of Aboriginal Title" (2002) 47 McGill LJ 473.

100 Campbell v British Columbia (2000) 189 DLR $\left(4^{\text {th }}\right) 333$ (BCSC).

101 Campbell $v$ British Columbia, above n 100, para 93 Williamson J.

102 Report on the Crown's Foreshore and Seabed Policy, above n 20, 6.

103 Foreshore and Seabed Act 2004, s 49(1)(b). 
small-scale matters such as gathering, hunting or waka landing. Individual physical manifestations of kaitiakitanga may have been rendered incapable of exercise, and thus removed from the factual matrix by virtue of section 50(1)(b)(iv). Whether or not they have been extinguished depends on the eventual interpretation given to the extingishment provisions. There are, in effect, two ways of looking at this issue. First, it may be argued that because they are mere physical manifestations, not the right actually claimed, they cannot be extinguished. Section 50(1)(c) contemplates the extinguishment of the activity, use or practice, of kaitiakitanga itself. Thus, at most, only small inroads may have been made into such a right as kaitiakitanga. Extinguishing events may have "nibbled" at the margins, and some physical manifestations may have been removed from the physical matrix, but the "bigger concept", kaitiakitanga, remains intact. Second, even if the physical manifestations can be extinguished, that still leaves the broader right intact. The broader the right claimed, the less likely that it has been entirely extinguished. Undoubtedly one of the reasons why the Australian High Court has characterised native title rights as analogous to "sticks in a bundle" is because such an approach simply makes it easier to selectively extinguish those sticks. ${ }^{104}$ This was recognised by North $\mathrm{J}$ in Western Australia $v$ Ward. In dissent his Honour held that native title is not a bundle of rights but a larger fundamental right to land. As a result, there can be no "partial extinguishment" of some of the sticks in the bundle. Extinguishment would only occur where there is a total and permanent inconsistency between the rights granted and the native title. ${ }^{105}$ That is a much more difficult thing to prove.

\section{CONCLUSION}

It is difficult to escape the conclusion that the Act has been drafted in order to ensure that only a narrow range of rights can be the subject of a CRO. The "bundling" approach, requirement of a physical manifestation, the layered extinguishment tests and exclusions from the ambit of CROs all point to a deliberate attempt to limit CROs to gathering and waka landing. In sections 49-51, the drafters have created a regime which is stricter, and which incorporates more onerous standards, than those found in other common law jurisdictions. This is a surprising outcome (as was the government's stance throughout the foreshore and seabed debate) given New Zealand's reputation as a country with a genuine commitment to reconciliation. Even if one accepts the Government's stated overall policy position - to secure access to the foreshore for all New Zealanders - it is unnecessary to limit Māori rights to such an extent in order to secure this aim. The government has simply opened New Zealand to the kind of criticism which has been levelled at Australia, and to a lesser degree Canada, for the poverty of the rights recognised by courts.

Will CROs deliver benefits? Obviously, much will depend on the approach taken by the Māori Land Court (as well as higher courts on appeal) to the construction of the CRO provisions. While

104 Western Australia v Ward, above n 17, para 26-29 Gleeson CJ, Gaudron, Gummow and Hayne JJ.

105 Western Australia v Ward (2000) 170 ALR 159 (FFC), paras 684, 689 and 711 North J. 
certain words and phrases do have a provenance in the case law of overseas jurisdictions, it has been frequently reiterated that the jurisdiction of the Māori Land Court is statutory, rather than based in the common law. And, as the final section of this paper has tried to indicate, the language of the legislation may bear a broader interpretation than is evident at first glance. So statutory jurisdiction should be seen not as a limitation, but as an invitation to ignore the restricted and limiting body of jurisprudence on which the provisions are modelled. While the Māori Land Court has been given a narrow jurisdiction, that jurisdiction has at least been given to a court which can work within both the confines of Western law and the realities of tikanga Māori. 
